\title{
ANALISIS KOMPETENSI PENYUSUNAN RENCANA PELAKSANAAN PEMBELAJARAN (RPP) GURU BAHASA ARAB MADRASAH TSANAWIYAH
}

\author{
Suyatno \\ Balai Diklat Keagamaan Semarang \\ suyatn0@kemenag.go.id
}

DOI: http://doi.org/10.37730/edutrained.v4i1.51

Diterima: 4 Februari 2020 | Disetujui: 11 April 2020 | Dipublikasikan: 6 Juli 2020

\begin{abstract}
Abstrak
Seorang guru wajib menyusun Rencana Pelaksanaan Pembelajaran berdasarkan silabus dan kompetensi dasar. Guru Bahasa Arab masih belum mampu memahami penyusunan Rencana Pelaksanaan Pembelajaran. Penelitian deskriptif kualitatif ini mengukur kemampuan peserta diklat yang nota bene adalah guru bahasa Arab di tingkat Tsanawiyah dalam penyusunan Rencana Pelaksanaan Pembelajaran. Data primer yang digunakan adalah dokumen Rencana Pelaksanaan Pembelajaran yang disusun oleh peserta diklat. Rencana Pelaksanaan Pembelajaran yang dibuat oleh peserta dianalisis melalui delapan komponen. Dengan menganalisis data yang terkumpul dengan memperhatikan petunjuk penyusunan didapatkan hasil bahwa dari delapan komponen atau aspek yang diteliti dalam penyusunan Rencana Pelaksanaan Pembelajaran, diketahui bahwa hanya komponen menyusun langkah-langkah pembelajaran, peserta mendapatkan predikat mampu. Ada tiga komponen peserta mendapatkan predikat cukup mampu, komponen lainnya memperoleh predikat kurang mampu. Dengan demikian dapat disimpulkan bahwa peserta diklat teknis substantif guru bahasa Arab tahun 2019, kurang mampu dalam menyusun Rencana Pelaksanaan Pembelajaran.
\end{abstract}

Kata Kunci: Bahasa Arab, Kompetensi Guru, RPP

\begin{abstract}
A teacher is required to draw up a Learning Implementation Plan based on syllabus and basic competencies. Arabic Language Teachers are still unable to understand the preparation of the Learning Implementation Plan. This qualitative descriptive study measures the ability of the training participants who are nota bene are Arabic language teachers at the Tsanawiyah level in preparing the Learning Implementation Plan. The primary data used is the Learning Implementation Plan document prepared by the training participants. Learning Implementation Plans made by participants were analyzed through eight components. By analyzing the data collected by taking into account the drafting instructions, it was found that from the eight components or aspects studied in the preparation of the Learning Implementation Plan, it was found that only the components composing the learning steps, participants got the title of being able to. There are three components of participants getting the title of capable enough, the other components getting the title of underprivileged. Thus it can be concluded that the participants of the substantive technical training of Arabic teachers in 2019, are less capable in preparing the Learning Implementation Plan.
\end{abstract}

Keywords: Arabic, Teacher Competence, Lesson Plan 


\section{PENDAHULUAN}

Pembelajaran merupakan pokok utama dalam kegiatan di sekolah. Tanpa ada kegiatan pembelajaran maka kegiatan di sekolah tidak terjadi proses pendidikan. Sehubungan dengan itu, maka pembelajaran yang direncanakan, dilaksanakan, dan dievaluasi oleh guru merupakan kegiatan pokok dan penting bagi kegiatan di sekolah. Kegiatan pembelajaran merupakan upaya guru untuk memberikan ilmu pengetahuan tentang berbagai hal yang bermanfaat kelak bagi siswanya. Pembelajaran yang dilaksanakan oleh guru juga mendidik siswanya untuk berperilaku yang baik sehingga mampu menjadi manusia yang berguna bagi dirinya, keluarga, masyarakat, serta bangsa dan negaranya. Pembelajaran merupakan bantuan yang diberikan pendidik agar dapat terjadi proses pemerolehan ilmu dan pengetahuan, penguasaan kemahiran dan tabiat, serta pembentukan sikap dan kepercayaan pada peserta didik. Dengan kata lain, pembelajaran adalah proses untuk membantu peserta didik agar dapat belajar dengan baik.

Pembelajaran dalam Kurikulum 2013 bertujuan mengembangkan bakat, minat, dan potensi peserta didik agar berkarakter, kompeten dan literat. Untuk mencapai hasil tersebut diperlukan pengalaman belajar yang bervariasi mulai dari yang bersifat sederhana sampai yang kompleks. Dalam kegiatan tersebut guru harus melaksanakan pembelajaran dan penilaian yang relevan dengan karakteristik pembelajaran abad 21 (Suryawan, 2017).

Rencana pembelajaran yang dibuat oleh guru bahasa Arab masih berbasis empat keterampilan yang sudah dilebur dalam Kurikulum 2013. Banyak guru bahasa Arab belum memahami penyusunan Kurikulum 2013 sesuai dengan kompetensi inti dan kompetensi dasar yang dituangkan dalam Keputusan Menteri Agama Nomor 165 Tahun 2014. Dalam komepetensi dasar yang disebutkan di Keputusan Menteri Agama Nomor 165 Tahun 2014 sama sekali tidak menyebutkan adanya empat keterampilan ( ). Misalnya pada kompetensi dasar 3.1 kelas 7, "Mengidentifikasi bunyi kata, frase, dan kalimat bahasa Arab yang berkaitan dengan:

$$
\begin{aligned}
& \text { التعريف بالنفس وبالعاملين في المدرسة؛ المرافق والأدوات } \\
& \text { المدرسية؛ الألوان؛ }
\end{aligned}
$$

Dari kompetensi dasar diatas, pembelajaran bahasa Arab pada Kurikulum 2013 berbasis tema dan teks, sementara empat keterampilan bahasa menjadi lebur. Namun demikian para guru masih membuat rencana pembelajaran berbasis empat keterampilan. Sehingga antara yang diajarkan dan tuntutan kompetensi pada kompetensi inti tidak tercapai. Akibatnya para peserta didik tidak mendapatkan kompetensi dasar yang dituntut.

Guru Bahasa Arab menyusun Rencana Pelaksanaan Pembelajaran masih belum mengacu kepada standar proses yang dijelaskan pada dokumen Kurikulum 2013 yang tertuang pada Permendikbud Nomor 22 Tahun 2016 tentang Standar Proses Pendidikan Dasar dan Menengah dan KMA 165 Tahun 2014 tentang pedoman kurikulum madrasah 2013 mapel Pendidikan Agama Islam dan bahasa Arab. RPP bahasa Arab yang dibuat oleh guru masih berbasis maharoh, empat keterampilan bahasa, mendengar, berbicara, membaca dan menulis. Model perumusan rencana pelaksanaan pembelajaran seperti ini masih mengikuti pola Kurikulum 2006 yang dalam pembelajaran bahasa arab masih menggunakan pendekatan maharah empat.

Sebagaimana dijelaskan di Permendikbud Nomor 22 Tahun 2016 tentang Standar Proses Pendidikan Dasar dan Menengah, setiap pendidik pada satuan pendidikan berkewajiban menyusun RPP secara lengkap dan sistematis agar pembelajaran berlangsung secara interaktif, inspiratif, menyenangkan, menantang, efisien, memotivasi peserta didik untuk berpartisipasi aktif. Rencana Pelaksanaan 
Pembelajaran selanjutnya disebut dengan RPP disusun berdasarkan Kompetensi Dasar atau tema yang dilaksanakan sekali pertemuan atau lebih.

Kemampuan guru bahasa Arab dalam menyusun rencana pelaksanaan pembelajaran perlu diperhatikan karena guru adalah kunci keberhasilan proses pencapaian hasil belajar siswa. Saat ini masih banyak guru yang RPPnya hanya hasil dari mengcopy dari orang lain tanpa melakukan analisis sesuai dengan karakteristik siswa. Akibatnya hasil belajar siswa belum memenuhi standar penilaian yang ditetapkan. Oleh karena itu, penelitian ini dilakukan untuk mendeskripsikan kemampuan peserta diklat teknis substantif guru bahsa Arab madrasah Tsanawiyah dalam menyusun rencana pelaksanaan pembelajaran sesuai dengan Kurikulum 2013.

\section{KAJIAN PUSTAKA}

Kemampuan atau kompetensi berasal dari bahasa Inggris competence, yang berarti kemampuan, keahlian, wewenang, dan kekuasaan. Hornby (1982: 172) mengartikan sebagai person having ability, power, authority, skill, knowledge to do what is needed. Berdasarkan dari pengertian ini maka kompetensi dapat diberi makna, orang yang memiliki kemampuan, kekuasaan, kewenangan, keterampilan, dan pengetahuan yang diperlukan untuk melakukan suatu tugas tertentu). Kompetensi menurut Steven M. Bornstein dan Antony F. Smith dalam The Leader of The Future (2000: 286) adalah keahlian dalam hard skill, keterampilan khusus, seperti keterampilan teknis, fungsional, content expertise skill, serta soft skill, seperti keterampilan interpersonal, komunikasi, tim dan organisasi.

Menurut E. Mulyasa yang dimaksud kompetensi adalah perpaduan dari pengetahuan, keterampilan, nilai dan sikap yang direfleksikan dalam kebiasaan berfikir dan bertindak. Selanjutnya beliau bahwa setiap sekolah mendiskrepsikan kompetensi-kompetensi secara jelas. Kompetensi tersebut meliputi: Kemampuan untuk belajar mengetahui (learning to know); kemampuan untuk belajar melakukan (learning to do); kemampuan belajar untuk hidup bersama (learning to live together); kemampuan untuk menjadi diri sendiri (learning to be); kemampuan untuk belajar seumur hidup (life long learning) (Mulyasa, 2005: 44).

Adapun kompetensi guru merupakan kemampuan seseorang guru dalam melaksanakan kewajiban kewajibannya secara bertanggung jawab dan layak. Dengan kata lain, kompetensi guru merupakan kemampuan dan kewenangan guru dalam melaksankan profesi keguruannya. Berdasarkan Permendiknas Nomor 16 Tahun 2007 tentang Standar Kualifikasi Akademik dan Kompetensi Guru, Standar Kompetensi Guru di bagi menjadi 4 aspek yaitu Kompetensi Paedagogik, Kompetensi Kepribadian, Kompetensi Profesional, dan Kompetensi Sosial. Kompetensi guru dalam menyusun RPP masuk dalam salah satu kompetensi paedagogik.

Berdasarkan Peraturan Pemerintah Republik Indonesia Nomor 74 Tahun 2008 Bab I Pasal I disebutkan bahwa guru adalah pendidik profesional dengan tugas utama mendidik, mengajar, membimbing, mengarahkan, melatih, menilai dan mengevaluasi peserta didik pada pendidikan anak usia dini jalur pendidikan formal, pendidikan dasar, dan pendidikan menengah. Untuk bisa melaksanakan tugas utamanya tersebut, maka setiap guru dituntut memiliki berbagai kemampuan yang akan membantu dalam melaksakan tugasnya. Beberapa kemampuan yang dipersyaratkan untuk dimiliki oleh guru tersebut dituangkan dalam kompetensi guru.

Peraturan Menteri Pendayagunaan Aparatur Negara dan Reformasi Birokrasi Nomor 16 tahun 2009 tentang Jabatan Fungsional Guru dan Angka kreditnya Pasal 13 ayat 2 disebutkan bahwa Rincian kegiatan Guru Mata Pelajaran sebagai berikut:

1. menyusun kurikulum pembelajaran pada satuan pendidikan;

2. menyusun silabus pembelajaran;

3. menyusun rencana pelaksanaan pembelajaran; 
4. melaksanakan

kegiatan pembelajaran;

5. menyusun alat ukur/soal sesuai mata pelajaran;

6. menilai dan mengevaluasi proses dan hasil belajar pada mata pelajaran yang diampunya;

7. menganalisis hasil penilaian pembelajaran;

8. melaksanakan pembelajaran/perbaikan dan pengayaan dengan memanfaatkan hasil penilaian dan evaluasi;

9. menjadi pengawas penilaian dan evaluasi terhadap proses dan hasil belajar tingkat sekolah dan nasional;

10. membimbing guru pemula dalam program induksi;

11. membimbing siswa dalam kegiatan ekstrakurikuler proses pembelajaran;

12. melaksanakan pengembangan diri;

13. melaksanakan publikasi ilmiah; dan

14. membuat karya inovatif.

Berdasarkan Peraturan Menteri Pendayagunaan Aparatur Negara dan Reformasi Birokrasi Nomor 16 tahun 2009 tentang Jabatan Fungsional Guru dan Angka kreditnya Pasal 13 ayat 2 tersebut jelas sekali disebutkan bahwa menyusun RPP merupakan salah satu bagian daririncian kegiatan Guru Mata Pelajaran, yang dalam hal ini guru Bahasa Arab termasuk di dalamnya. Sehingga menyusun RPP merupakan salah satu bagian dari sekian banyak kewajiban guru disamping kewajiban-kewajiban yang lain yang harus dilaksanakan oleh guru.

Dari uraian di atas dapat diambil kesimpulan bahwa guru diharapkan memiliki kemampuan untuk menyusun rencana pelaksanaan pembelajaran (RPP) secara profesional. Semiawan (1991) dalam Prof. Dr. Sudarwan Danim (2002: 31) mengemukakan hierarki profesi tenaga kependidikan, yaitu, (1) tenaga professional, (2) tenaga semi professional, dan (3) tenaga para-profesional.

1. Tenaga profesional merupakan tenaga kependidikan yang berkualifikasi pendidikan sekurang-kurangnya S1 (atau yang setara), dan memiliki wewenang penuh dalam perencanaan, pelaksanaan, penilaian dan pengendalian pendidikan atau pengajaran. Tenaga kependidikan yang termasuk dalam kategori ini juga berwenang untuk membina tenaga kependidikan yang lebih rendah jenjang profesionalnya.

2. Tenaga semiprofessional merupakan tenaga kependidikan yang berkualifikasi pendidikan tenaga D3 (atau yang setara) yang telah berwenang mengajar secara mandiri, tetapi masih harus melakukan konsultasi dengan tenaga kependidikan yang lebih tinggi jenjang profesionalnya, baik dalam hal perencanaan, pelaksanaan, penilaian maupun pengendalian pengajaran

3. Tenaga paraprofessional merupakan tenaga kependidikan yang berkualifikasi pendidikan tenaga kependidikan D2 ke bawah, yang memerlukan pembinaan dalam perencanaan, pelaksanaan, penilaian dan pengendalian pendidikan atau pengajaran.

Sardiman A.M (2001:142-144) menyebutkan bahwa guru memiliki beberapa peranan, yaitu :

1. Informator: Sebagai pelaksana cara mengajar informative, laboratorium, studi lapangan dan sumber informasi kegiatan akademik maupun umum

2. Organisator: Sebagai pengelola kegiatan akademik, silabus, workshop, jadwal pelajaran, dll.

3. Motivator: Guru harus dapat merangsang dan memberikan dorongan serta reinforcement untuk mendinamisasikan potensi siswa, menumbuhkan swadaya (aktivitas) dan daya cipta (kreatifitas) sehingga akan terjadi dinamika di dalam proses pembelajaran.

4. Pengarah/director: Guru dalam hal ini harus dapat membimbing dan mengarahkan kegiatan belajar siswa sesuai dengan tujuan pembelajaran.

5. Inisiator: Guru sebagai pencetus ideide kreatif dalam proses pembelajaran yang dapat dicontoh oleh siswanya. 
6. Tramsmitter: Guru harus mampu bertindak selaku penyebar kebijakan pendidikan dan pengetahuan

7. Fasilitator: Guru dalam hal ini akan memberikan fasilitas atau kemudahan dalam proses pembelajaran, misalnya dengan mengupayakan terciptanya proses pembelajaran yang efektif.

8. Mediator: Guru sebagai penengah dalam kegiatan belajar siswa. Misal guru memberikan jalan keluar kemacetan dalam kegiatan diskusi siswa.

9. Evaluator: Guru mempunyai otoritas utnuk menilai prestasi anak didik dalam bidang akademis maupun tingkah laku sosialnya, sehingga dapat menentukan bagaimana anak didiknya berhasil atau tidak.

Dari beberapa uraian yang ada kaitannya dengan kompetensi guru, tugas dan kewajiban guru, serta peranan guru ini diharapkan akan mampu membawa kearah profesionalitas guru pada umumnya maupun guru bahasa Arab pada khususnya. Dengan demikian harapan kita bersama untuk memajukan dan meningkatkan kualitas pendidikan untuk bangsa ini akan menjadi kenyataan. Untuk meraih harapan ini tentu saja diperlukan kerja keras dan saling mendukung antara unsur yang satu dengan unsur yang lainnya, mengingat bahwa pendidikan sejatinya adalah menjadi tanggung jawab kita bersama.

\section{Rencana Pelaksanaan Pembelajaran}

Prastowo (2017; 30) menyatakan bahwa dengan berubahnya pendekatan pembelajaran, berubah pula beberapa hal yang terkait dengannya, diantaranya adalah desain pembelajaran, pegorganisasian materi, langkah-langkah pembelajaran, maupun penilaiannya. Menurut Prastowo, perencanaan pembelajaran merupakan kegiatan menterjemahkan sekolah dalam kegiatan pembelajaran sehari-hari di kelas (Prastowo, 2017;30).

Pertama kali yang harus dilakukan oleh seorang guru sebelum melaksanakan tugas mengajar di kelas, adalah menyusun rencana pembelajaran Wina Sanjaya (2010: 28-29) menjelaskan pengertian perencanaan pembelajaran adalah proses pengambilan keputusan hasil berpikir secara rasional tentang sasaran dan tujuan pembelajaran tertentu, yakni perubahan perilaku serta rangkaian kegiatan yang harus dilaksanakan sebagai upaya pencapaian tujuan tersebut dengan memanfaatkan segala potensi dan sumber belajar yang ada. Hasil akhir dari proses pengambilan keputusan tersebut adalah tersusunnya dokumen yang berisi tentang hal-hal terkait dengan proses pembelajaran, sehingga selanjutnya dokumen tersebut dapat dijadikan sebagai acuan dan pedoman dalam melaksanakan proses pembelajaran.

Selanjutnya Wina Sanjaya (2010: 29) menjelaskan bahwa perencanaan pembelajaran memiliki karakteristik sebagai berikut :

1. Perencanaan

pembelajaran merupakan hasil dari proses berpikir, disusun dengan mempertimbangkan segala aspek yang mungkin dapat berpengaruh, di samping disusun dengan mempertimbangkan segala sumber daya yang tersedia yang dapat mendukung terhadap keberhasilan proses pembelajaran.

2. Perencanaan pembelajaran disusun untuk mengubah perilaku siswa sesuai dengan tujuan tujuan yang ingin dicapai. Ini berarti fokus utama dalam pembelajaran adalah ketercapaian tujuan.

3. Perencanaan pembelajaran berisi tentang rangkaian kegiatan yang harus dilaksanakan untuk mencapai tujuan. Oleh karena itulah, perencanaan pembelajaran dapat berfungsi sebagai pedoman dlam mendesain pembelajaran sesuai dengan kebutuhan.

Rencana Pelaksanaan Pembelajaran (RPP) adalah rencana kegiatan pembelajaran tatap muka untuk satu pertemuan atau lebih. RPP dikembangkan dari silabus untuk mengarahkan kegiatan pembelajaran peserta didik dalam upaya mencapai Kompetensi Dasar (KD). Setiap 
pendidik pada satuan pendidikan berkewajiban menyusun RPP secara lengkap dan sistematis agar pembelajaran berlangsung secara interaktif, inspiratif, menyenangkan, menantang, efisien, memotivasi peserta didik untuk berpartisipasi aktif, serta memberikan ruang yang cukup bagi prakarsa, kreativitas, dan kemandirian sesuai dengan bakat, minat, dan perkembangan fisik serta psikologis peserta didik. RPP disusun berdasarkan KD atau subtema yang dilaksanakan kali pertemuan atau lebih.

Komponen RPP terdiri atas:

1. identitas sekolah yaitu nama satuan pendidikan;

2. identitas mata pelajaran atau tema/subtema;

3. kelas/semester;

4. materi pokok;

5. alokasi waktu ditentukan sesuai dengan keperluan untuk pencapaian KD dan beban belajar dengan mempertimbangkan jumlah jam pelajaran yang tersedia dalam silabus dan KD yang harus dicapai;

6. tujuan pembelajaran yang dirumuskan berdasarkan KD, dengan menggunakan kata kerja operasional yang dapat diamati dan diukur, yang mencakup sikap, pengetahuan, dan keterampilan;

7. kompetensi dasar dan indikator pencapaian kompetensi;

8. materi pembelajaran, memuat fakta, konsep, prinsip, dan prosedur yang relevan, dan ditulis dalam bentuk butir-butir sesuai dengan rumusan indikator ketercapaian kompetensi;

9. metode pembelajaran, digunakan oleh pendidik untuk mewujudkan suasana belajar dan proses pembelajaran agar peserta didik mencapai KD yang disesuaikan dengan karakteristik peserta didik dan KD yang akan dicapai;

10. media pembelajaran, berupa alat bantu proses pembelajaran untuk menyampaikan materi pelajaran;

11. sumber belajar, dapat berupa buku, media cetak dan elektronik, alam sekitar, atau sumber belajar lain yang relevan;
12. langkah-langkah pembelajaran dilakukan melalui tahapan pendahuluan, inti, dan penutup;

13. penilaian hasil pembelajaran. (Permendikbud Nomor 23 Tahun 2016).

\section{Prinsip Penyusunan RPP}

Dalam menyusun RPP hendaknya memperhatikan prinsip-prinsip sebagai berikut:

1. Perbedaan individual peserta didik antara lain kemampuan awal, tingkat intelektual, bakat, potensi, minat, motivasi belajar, kemampuan sosial, emosi, gaya belajar, kebutuhan khusus, kecepatan belajar, latar belakang budaya, norma, nilai, dan/atau lingkungan peserta didik.

2. Partisipasi aktif peserta didik.

3. Berpusat pada peserta didik untuk mendorong semangat belajar, motivasi, minat, kreativitas, inisiatif, inspirasi, inovasi dan kemandirian.

4. Pengembangan budaya membaca dan menulis yang dirancang untuk mengembangkan kegemaran membaca, pemahaman beragam bacaan, dan berekspresi dalam berbagai bentuk tulisan.

5. Pemberian umpan balik dan tindak lanjut RPP memuat rancangan program pemberian umpan balik positif, penguatan, pengayaan, dan remedi.

6. Penekanan pada keterkaitan dan keterpaduan antara KD, materi pembelajaran, kegiatan pembelajaran, indicator pencapaian kompetensi, penilaian, dan sumber belajar dalam satu keutuhan pengalaman belajar.

7. Mengakomodasi pembelajaran tematik terpadu, keterpaduan lintas mata pelajaran, lintas aspek belajar, dan keragaman budaya.

8. Penerapan teknologi informasi dan komunikasi secara terintegrasi, sistematis, dan efektif sesuai dengan situasi dan kondisi. (Permendikbud Nomor 22 Tahun 2016). 


\section{Karakteristik Pembelajaran Kurikulum 2013}

Karakteristik pembelajaran Kurikulum 2013 pada setiap satuan pendidikan terkait erat pada Standar Kompetensi Lulusan dan Standar Isi. Standar Kompetensi Lulusan memberikan kerangka konseptual tentang sasaran pembelajaran yang harus dicapai. Standar Isi memberikan kerangka konseptual tentang kegiatan belajar dan pembelajaran yang diturunkan dari tingkat kompetensi dan ruang lingkup materi. Sesuai dengan Standar Kompetensi Lulusan, sasaran pembelajaran mencakup pengembangan ranah sikap, pengetahuan, dan keterampilan yang dielaborasi untuk setiap satuan pendidikan. Ketiga ranah kompetensi tersebut memiliki lintasan perolehan (proses psikologis) yang berbeda. Sikap diperoleh melalui aktivitas "menerima, menjalankan, menghargai, menghayati, dan mengamalkan". Pengetahuan diperoleh melalui aktivitas "mengingat, memahami, menerapkan, menganalisis, mengevaluasi, mencipta". Keterampilan diperoleh melalui aktivitas "mengamati, menanya, mencoba, menalar, menyaji, dan mencipta".

Karaktersitik kompetensi beserta perbedaan lintasan perolehan turut serta mempengaruhi karakteristik standar proses. Untuk memperkuat pendekatan ilmiah (scientific), tematik terpadu (tematik antar matapelajaran), dan tematik (dalam suatu mata pelajaran) perlu diterapkan pembelajaran berbasis penyingkapan/penelitian

(discovery/inquiry learning). Untuk mendorong kemampuan peserta didik untuk menghasilkan karya kontekstual, baik individual maupun kelompok maka sangat disarankan menggunakan pendekatan pembelajaran yang menghasilkan karya berbasis pemecahan masalah (project based learning) (Permendikbud Nomor 22 Tahun 2016).

\section{METODE PENELITIAN}

Penelitian ini menggunakan metode kualitatif deskriptif, menafsirkan dan menginterpretasi data yang diperoleh oleh peneliti dengan membuat ukuran keberhasilan sesuai dengan peraturan yang berlaku. Moelong dalam Agung S menyatakan bahwa penelitian kualitatif adalah prosedur penelitian yang menghasilkan data deskriptif berupa katakata tertulis atau lisan dari orang-orang dan perilaku yang dapat diamati (Agung S; 2012).

Metode penelitian ini digunakan oleh penulis karena menurut Djam'an Satori (2011: 23) bahwa penelitian kualitatif dilakukan karena peneliti ingin mengeksplor fenomena-fenomena yang tidak dapat dikuantifikasikan yang bersifat deskriptif seperti proses suatu langkah kerja, formula suatu resep, pengertian-pengertian tentang suatu konsep yang beragam, karakteristik suatu barang dan jasa, gambargambar, gayagaya, tata cara suatu budaya, model fisik suatu artifak dan lain sebagainya. Penulis hendak mengungkapkan fakta tentang kemampuan para guru bahasa Arab yang sedang mengikuti diklat teknis substantif guru bahasa Arab Madrasah Tsanawiyah di Balai Diklat Keagamaan Semarang. Penelitian ini untuk mendeskripsikan kemampuan yang dimiliki para guru bahasa Arab dalam menyusun Rencana Pelaksanaan Pembelajaran (RPP) berbasis Kurikulum 2013.

Sugiono (2012: 9) juga mengemukakan penelitian kualitatif sebagai metode penelitian yang berlandaskan pada filsafat postpositivisme, digunakan untuk meneliti pada kondisi objek alamiah, dimana peneliti adalah sebagai instrumen kunci, teknik pengumpulan data dengan triangulasi, analisis data bersifat induktif atau kualitatif, dan hasil penelitian kualitatif lebih menekankan makna daripada generalisasi. Penelitian ini diharapkan dapat memaknai kemampuan yang telah dimiliki oleh guru bahasa Arab dalam penyusunan RPP.

Menurut Nana Syaodih Sukmadinata (2011: 73), penelitian deskriptif kualitatif ditujukan untuk mendeskripsikan dan 
menggambarkan fenomena-fenomena yang ada, baik bersifat alamiah maupun rekayasa manusia, yang lebih memperhatikan mengenai karakteristik, kualitas, keterkaitan antar kegiatan. Selain itu, penelitian deskriptif tidak memberikan perlakuan, manipulasi atau pengubahan pada variabel-variabel yang diteliti, melainkan menggambarkan suatu kondisi yang apa adanya. Satu-satunya perlakuan yang diberikan hanyalah penelitian itu sendiri, yang dilakukan melalui observasi, wawancara, dan dokumentasi.

Peneliti menggunakan metode penelitian deskriptif kualitatif karena penelitian ini mengeksplor fenomena kemampuan peserta diklat teknis substantif guru bahasa Arab Madrasah Tsanwiyah dalam menyusun Rencana Pelaksanaan Pembelajaran Mata Pelajaran Bahasa Arab. Teknik pengumpulan data yang digunakan adalah teknik dokumentasi. Dokumentasi yang dimaksud dalam penelitian ini adalah RPP yang disusun oleh peserta diklat teknis substantif guru bahasa Arab. Teknik dokumentasi ini digunakan sebagai satusatunya teknik untuk mengumpulkan data tentang kemampuan guru bahasa Arab dalam menyusun RPP tahun ajaran 20182019. Teknik pengumpulan data dengan dokumentasi ini sangat berperan dalam pengambilan keputusan peneliti pada saat mendeskripsikan hasilnya.

Peneliti mendokumentasi seluruh RPP yang disusun oleh para guru bahasa Arab yang sedang mengikuti diklat teknis substantif guru bahasa Arab Madrasah Tsanawiyah. RPP yang dikumpulkan adalah RPP yang mereka gunakan seharihari dalam pembelajaran di madrasahnya masing-masing. RPP sangat berpengaruh terhadap kualitas pembelajaran maupun hasil dari sebuah pembelajaran. Karena RPP disusun dengan mempertimbangkan karakteristik siswa pada madrasah tertentu.

Analisis data penelitian kualitatif ini menggunakan teknik analisis model interaktif. model analisis data secara interaktif, yaitu suatu proses yang bersifat siklus antara tahap penyediaan data dan analisa data sampai tahap penyajian hasil analisis yang berupa pemaparan dan penegasan simpulan (Miles dan Huberman dalam Tizar Rahmawan, 2009)

Subjek penelitian ini adalah guru Madrasah Tsanawiyah dari seluruh wilayah kerja Balai Diklat Keagamaan Semarang meliputi Propinsi Jawa Tengah dan D.I. Yogyakarta, yang sedang mengikuti Diklat Teknis Substantif Bahasa Arab bagi Guru Madrasah Tsanawiyah. Para guru yang menjadi peserta diklat ini menjadi informan utama.

\section{Teknik Pengumpulan dan Analisis Data}

Teknik pengumpulan data, penulis menggunakan tiga cara pengumpulan data, dokumentasi, observasi dan wawancara. Penulis melakukan observasi pada obyek penelitian sebagai sumber data dalam keadaan asli atau sebagaimana keadaan sehari-hari. Penulis melakukan observasi langsung dalam penelitian ini untuk mengungkap data yang riil dan jelas mengenai penyusunan Rencana Pelaksanaan Pembelajaran (RPP).

Yang paling utama sebagi bukti data dari penelitian ini adalah dokumentasi data. Peneliti mengumpulkan Rencana Pelaksanaan Pembelajaran (RPP) yang dibuat oleh peserta diklat sebelum mereka mengikuti diklat. Seluruh peserta diklat mengumpulkan RPP yang mereka miliki. RPP yang sudah di print out oleh peserta diklat ini menjadi sumber utama dari penelitian ini. Peneliti menetapkan fokus penelitian, memilih informan sebagai sumber data, melakukan pengumpulan data, menilai kualitas data, analisis data, menafsirkan data, membuat kesimpulan atas temuannya, dan akhirnya peneliti menjadi pelapor hasil penelitiannya

Menurut Sugiyono (2009: 335-336), analisis data merupakan proses mencari dan menyusun secara sistematis data yang diperoleh dari hasil wawancara, observasi, dan dokumentasi, dengan cara mengorganisasikan data ke dalam kategori, menjabarkan ke dalam unit-unit, melakukan sintesa, menyusun ke dalam pola, memilih mana yang penting dan yang 
akan di pelajari, dan membuat kesimpulan sehingga mudah dipahami oleh diri sendiri dan orang lain. Aktivitas dalam analisis data kualitatif dilakukan secara interaktif dan berlangsung secara terus menerus sampai tuntas, sehingga datanya sudah jenuh.

Langkah-langkah analisis yang digunakan dalam penelitian ini sebagai berikut. Proses analisis data dalam penelitian ini yang berupa studi dokumentasi adalah peneliti mengumpulkan RPP yang digunakan guru Bahasa Arab yang sedang mengikuti Diklat Teknis Substantif Guru Bahasa Arab Madrasah Tsanawiyah di Balai Diklat Keagamaan Semarang. Setelah RPP terkumpul dan data diklasifikasikan berdasarkan kelas, empat keterampilan berbahasa, dan kompetensi dasar. RPP dianalisis sesuai dengan komponen yang diamati dalam Rubrik Panduan Penyusunan RPP dengan menggunakan skoring. Rubrik tidak digunakan untuk menilai melainkan digunakan sebagai panduan proses analisis data (analisis verbal). Analisis pada Rubrik Panduan Penyusunan RPP diberi skor antara 1 sampai 4. Jika aspek yang terdapat dalam RPP yang diteliti sesuai dengan kriteria dalam Rubrik Panduan Penyusunan RPP diberi skor dengan tingkat kesesuaiannya. Langkah selanjutnya adalah analisis verbal dari hasil chek list. Peneliti menjabarkan/mendeskripsikan hasil skor secara verbal berdasarkan teori tentang komponen RPP dan pengembangannya. Teori tersebut digunakan untuk menunjang data tentang (1) kemampuan mengembangkan indikator, (2) kemampuan merumuskan tujuan pembelajaran, (3) Kemampuan menentukan materi/bahan ajar, (4) kemampuan menentukan sumber belajar, (5) kemampuan menentukan metode pembelajaran, (6) kemampuan menentukan media pembelajaran, (7) kemampuan menyusun langkah-langkah pembelajaran, dan (8) Kemampuan merancang penilaian pembelajaran.

Keabsahan data diperlukan teknik pemeriksaan yang didasarkan pada sejumlah kriteria tertentu, diantaranya adalah kredibilitas, kebergantungan dan kepastian. Untuk menjamin keabsahan data maka dalam penelitian dilakuan triangulasi data. Triangulasi adalah teknik pemeriksaan keabsahan data dengan memanfaatkan sesuatu yang lain diluar data untuk keperluan pengecekan atau sebagai pembanding terhadap data tersebut.

Dalam menganalisis data untuk menentukan predikat dari kemampuan peserta diklat dalam menyusun Rencana Pelaksanaan Pembelajaran, penulis membuat kriteria penilaian melalui skoring dari setiap komponen. Ada delapan komponen yang dianalisis adalah; (1) kemampuan mengembangkan indikator, (2) kemampuan merumuskan tujuan pembelajaran, (3) Kemampuan menentukan materi/bahan ajar, (4) kemampuan menentukan sumber belajar, (5) kemampuan menentukan metode pembelajaran, (6) kemampuan menentukan media pembelajaran, (7) kemampuan menyusun langkah-langkah pembelajaran, dan (8) Kemampuan merancang penilaian pembelajaran. masing-masing komponen diberi skor dengan melihat kriteria pada Tabel 1.

Tabel 1. Kriteria skor

\begin{tabular}{c|c|c}
\hline No & Kriteria & Skor \\
\hline 1 & Tidak Sesuai & 1 \\
\hline 2 & Kurang Sesuai & 2 \\
\hline 3 & Cukup Sesuai & 3 \\
\hline 4 & Sangat Sesuai & 4 \\
\hline
\end{tabular}

Masing-masing komponen dianalisis diberi skor sesuai dengan kondisi dan fakta yang ada didokumen. Dari dokumen yang dianalisis diberikan skor paling tinggi 4, jika komponen yang bersangkutan sangat sesuai dengan juknis penulisan Rencana Pelaksanaan Pembelajaran maka mendapatkan skor 4. Apabila guru menulis komponen RPP sesuai tetapi belum 
sempurna, maka mendapatkan skor 3 dan seterusnya.

Setelah mentukan skoring setiap komponen, langkah berikutnya adalah menentukan kriteria kemampuan peserta dalam menyusun Rencana Pelaksanaan Pembelajaran dengan skala sebagai berikut:

Tabel 2. Tabel kriteria kemampuan peserta

\begin{tabular}{l|l|l}
\hline No & Predikat & Nilai \\
\hline 1 & Sangat Mampu & $>=88$ \\
\hline 2 & Mampu & $>=75$ \\
\hline 3 & Cukup Mampu & $>=60$ \\
\hline 4 & Kurang Mampu & $<60$ \\
\hline
\end{tabular}

Dari masing-masing komponen setelah didapatkan skor, maka kemudian dihitung dan dijumlahkan. Dari perolehan skor, kemudian dibagi dengan skor maksimal dan dikalikan 100 untuk mendapatkan nilai akhir. Dari nilai akhir yang didapat, kemudian diketahui tingkat kemampuannya dalam menyusun rencana pelaksanaan pembelajaran.

\section{HASIL PENELITIAN DAN PEMBAHASAN}

\section{Hasil Penelitian}

Penyusunan RPP menjadi salah satu tanggung jawab guru yang menjadi motor penggerak dalam pelaksanaan pembelajaran. Idealnya, RPP merupakan potret riil pembelajaran yang akan dilaksanakan oleh guru. Dalam hal ini, RPP merupakan rancangan pembelajaran mulai dari awal pembelajaran sampai dengan penilaian akhir. Oleh karena itu, dapat dikatakan bahwa pemahaman guru dalam menerapkan Kurikulum 2013 revisi 2017 dapat dilihat dari hasil guru menyusun RPP, apabila RPP yang disusunnya sudah baik, maka dapat dikatakan guru sudah memahami semangat Kurikulum 2013 revisi 2017.

Pembelajaran sesuai dengan amanat Kurikulum 2013 untuk menampilkan. Realisasi dari penerapan keempat hal tersebut akan dapat dilihat secara terpadu melalui rancangan pelaksanaan pembelajaran yang disusun oleh guru dalam bentuk RPP.

Berdasarkan data yang diteliti oleh penulis, didapatkan hasil sebagai berikut

\begin{tabular}{|l|c|l|}
\hline No & Aspek & Nilai \\
\hline 1 & 1 & 46 \\
\hline 2 & 2 & 51.40 \\
\hline 3 & 3 & 51.40 \\
\hline 4 & 4 & 55.70 \\
\hline 5 & 5 & 60 \\
\hline 6 & 6 & 64.30 \\
\hline 7 & 7 & 75.70 \\
\hline 8 & 8 & 75.70 \\
\hline
\end{tabular}

\section{Pembahasan}

Berikut deskripsi secara rinci tiap komponen dalam RPP yang disusun oleh peserta diklat teknis substantif guru bahasa Arab Madrasah Tsanawiyah:

\section{a. Kemampuan Mengembangkan Indikator}

Indikator dikembangkan dari Kompetensi Dasar (KD), merupakan kemampuan minimal yang dapat diobservasi sebagai pemenuhan KD dalam Kompetensi Inti (KI). Indikator disusun menggunakan kata kerja operasional yang dapat diukur/dilakukan penilaian sesuai karakteristik mata pelajaran. Guru bahasa Arab dalam mengembangkan indikator, mendapat nilai 46, atau masuk dalam kategori kurang mampu. Guru bahasa Arab dalam mengembangkan indikator masih banyak yang belum menggunaan Kata Kerja Operasional. Pengembangan indikator menggunakan kata kerja operasional agar dapat diukur dalam rangka penilian. Guru bahasa Arab dalam mengembangkan indikator, masih belum bisa membedakan antara indikator dan kegiatan pembelajaran. kegiatan pembelajaran ditulis sebagai indikator. Masih banyak guru yang dalam satu paket pembelajaran indikator tidak melengkapi indikator untuk kompetensi dasar dari kompetensi Inti 3 dan Kompetensi Inti 4. Indikator dikembangkan untuk memenuhi tunutan kompetensi dasar. Sehingga dengan tercapainya indikator, peserta mampu menguasai kompetensi dasar yang dituju. Dari data yang masuk, banyak sekali guru yang membuat indikator masih 
jauh dari ketercapaian kompetensi. Misalnya, kompetensi dasar pada level 2 taksonomi bloom, seharusnya indikator minimal mencapai level pengetahuan itu, atau melebihi, tetapi tidak boleh dibawah level.

\section{b. Kemampuan merumuskan tujuan pembelajaran}

Tujuan pembelajaran dirumuskan berdasarkan KD dengan menggunakan kata kerja operasional yang dapat diamati dan diukur, mencakup aspek sikap, pengetahuan, dan keterampilan. Tujuan pembelajaran dituangkan dalam bentuk deskripsi, memuat kompetensi yang hendak dicapai oleh peserta didik, menggambarkan proses pembelajaran dan pencapaian hasil pembelajaran. dari penilaian dari data yang masuk, skornya hanya mencapai 51, 40, atau hanya memiliki predikat kurang mampu. Dari analisis data didapatkan fakta bahwa peserta belum memiliki kemampuan yang cukup untuk merumuskan tujuan pembelajaran. tujuan pembelajaran sangat urgen dalam sebuah rancangan pembelajaran. Karena dengan tujuan yang jelas dan memuat cara serta metode pencapaian indikator kompetensi maka guru akan semakin mudah melakukan pembelajaran yang menghasilkan kemampuan peserta didik. Dalam dokumen rencana pelaksanaan pembelajaran, masih banyak guru yang tidak menuliskan rumusan tujuan pembelajaran. Guru tidak menuliskan tujuan pembelajaran dikarenakan beberapa kemungkinan, karena tidak memahami Permendikbud Nomor 22 Tahun 2016 tentang Standar Proses. Dalam regulasi tersebut dijelaskan detail komponen rencana pelaksanaan pembelajaran yang tidak kurang dari 11 komponen. Diantara komponenkomponen tersebut, seorang guru harus menuliskan rumusan tujuan pembelajaran. Kemungkinan lainnya, adalah RPP yang dimiliki bukan buatannya sendiri, sehingga peserta tidak meneliti lagi bahwa di RPP yang dimiliki tidak ada rumusan tujuan pembelajarannya. Dari data dokumen yang diamati oleh peneliti, ditemui bahwa masih sangat banyak, bahkan mendekati t, guru bahasa Arab merumuskan tujuan pembelajaran tidak berdasarkan indikator yang dibuat. Antara indikator dan tujuan pembelajaran tidak sinkron, sehingga apa yang dingin dicapai dengan apa yang dilakukan tidak sama. Hal ini akan berdampak buruk pada proses pembelajaran. Yang menjadi masalah berikutnya adalah, ketika indikator yang disusun tidak sesuai dengan tuntutan kompetensi dasar, kemudian dirumuskan tujuan pembelajaran tidak sesuai dengan indikator yang dibuat. Kondisi seperti ini banyak dijumpai di rencana pelaksanaan pembelajaran yang dimiliki oleh para guru bahasa Arab Madrasah Tsanawiyah yang menjadi sampling.

\section{c. Kemampuan materi/bahan ajar \\ menentukan}

Sesuai dengan kriteria penentuan materi/bahasa ajar, materi pembelajaran yang dirancang memuat konsep/prinsip dan prosedur yang relevan dan sesuai dengan rumusan indikator ketercapaian kompetensi. Kemampuan guru bahasa Arab dalam menentukan materi dan bahan ajar mendapat nilai 51, dengan predikat kurang mampu. Temuan ini didapat dari dokumen rencana pelaksanaan pembelajaran guru bahasa Arab madrasah Tsanawiyah yang menjadi sampling. Materi yang ditulis di Rencana Pelaksanaan Pembelajaran tidak sesuai dengan indikator dan kompetensi yang ingin di capai. Rata-rata guru menulis materi dalam RPP dengan mencantumkan tema dan isi kandungan tema di buku guru.

\section{d. Kemampuan menentukan sumber belajar}

Sumber belajar yang mendukung ketercapaian hasil belajar adalah sumber belajar yang dapat memenuhi kebutuhan materi pembelajaran, diambil dari sumber yang dapat dipertanggungjawabkan, dan dapat memotivasi peserta didik dalam belajar. Dari hasil penilaian dokumen yang dikumpulkan, kemampuan guru bahasa Arab dalam menentukan sumber belajar mendapatkan nilai 55,70 dengan predikat kurang mampu. Hampir semua guru bahasa Arab dala menuliskan sumber belajar, tidak ditulis dengan cara penulisan ilmiah. Sumber belajar yang disebutkan 
atau yang digunakan dalam pembelajaran masih mengacu ke hanya buku paket tidak ada sumber di luar buku paket. Buku paket yang dibuat pemerintah merupakan standar minimal, guru perlu mengembangkan sumber belajar dan mencari sebanyak-banyaknya sumber belajar untuk menciptakan pembelajaran yang menarik dan variatif. Dengan hanya mengandalkan buku paket saja, dipastikan pembelajaran tidak variatif dan membosankan.

\section{e. Kemampuan menentukan metode pembelajaran}

Metode pembelajaran adalah suatu cara atau prosedur yang dilakukan oleh guru agar proses belajar-mengajar dapat berjalan secara efektif. Metode pembelajaran dikategorikan baik apabila mampu mewujudkan suasana belajar dan proses pembelajaran yang sesuai dengan karakteristik siswa. Menerapkan pembelajaran aktif yang bermuara pada pengembangan HOTS. Mampu menggambarkan sintak atau tahapan yang jelas dari metode yang digunakan dan menggambarkan proses pencapaian kompetensi. Dari data yang diperoleh peneliti, kemampuan guru bahasa Arab dalam menentukan dan memilih model pembelajaran memperoleh skor 60, dengan predikat cukup mampu. Dari dokumen yang ditelaah peneliti didapatkan bahwa sebagian guru dalam RPP nya tidak menuliskan metode. Guru lain dalam RPP nya memilih metode tidak sama dengan yang disebutkan di tujuan pembelajaran. Metode yang dipakai tidak sinkron dengan proses yang disebutkan dalam tujuan pembelajaran. belum lagi yang tidak menuliskan tujuan pembelajaran. Metode seharusnya disebutkan untuk menjelaskan proses dalam pembelajaran dalam rangka mencapai kompetensi yang diinginkan oleh kompetensi dasar melalui indikator.

\section{f. Kemampuan menentukan media pembelajaran}

Media pembelajaran adalah alat bantu yang digunakan oleh guru atau siswa dalam proses pembelajaran dengan tujuan untuk mempermudah penyampaian dan pemahaman materi yang dipelajari. Media pembelajaran yang baik adalah media yang dapat mendukung pencapaian kompetensi dan pembelajaran aktif dengan pendekatan ilmiah, sesuai dengan karakteristik peserta didik, dan dapat memanfaatkan teknologi pembelajaran sesuai dengan konsep dan prinsip tekno pedagogis. Dari data yang diperoleh peneliti, kemampuan guru bahasa Arab dalam menentukan media pembelajaran memperoleh skor 64,30 dengan predikat cukup mampu. Media yang digunakan para guru bahasa Arab dalam pembelajaran, baik pembelajaran yang memerlukan peralatan khusus, misalkan pembelajaran yang menuntut menyimak, berbicara, menbaca dan menulis, menggunakan media standar, seperti laptop, LCD dan power point. Media ini sangat penting untuk pembelajaran bahasa asing, termasuk bahasa Arab, agar pembelajaran lebih mudah dan bermakna bagi peserta didik. Dari seluruh dokumen yang diamati, jarang sekali guru yang menggunakan alat peraga pembelajaran. Alat peraga pembelajaran sangat dibutuhkan dalam belajar bahasa. Peserta didik membutuhkan alat peraga untuk dapat menangkap pembelajaran dengan mudah.

\section{g. Kemampuan menyusun langkah- langkah pembelajaran}

Langkah-langkah pembelajaran dilakukan melalui tahapan pendahuluan, inti, dan penutup. Dalam kegiatan pendahuluan, guru wajib:

1) menyiapkan peserta didik secara psikis dan fisik untuk mengikuti proses pembelajaran

2) memberi motivasi belajar peserta didik secara kontekstual sesuai manfaat dan aplikasi materi ajar dalam kehidupan sehari-hari

3) menjelaskan tujuan pembelajaran atau kompetensi dasar yang akan dicapai.

Dalam kegiatan inti, menggunakan model pembelajaran, metode pembelajaran, media pembelajaran, dan sumber belajar yang disesuaikan dengan karakteristik peserta didik dan mata pelajaran. Pemilihan pendekatan tematik dan /atau tematik terpadu dan/atau saintifik dan/atau inkuiri dan 
penyingkapan (discovery) dan/atau pembelajaran yang menghasilkan karya berbasis pemecahan masalah (project based learning) disesuaikan dengan karakteristik kompetensi dan jenjang pendidikan.

Dalam kegiatan penutup, guru bersama peserta didik baik secara individual maupun kelompok melakukan refleksi untuk mengevaluasi. Memberikan umpan balik terhadap proses dan hasil pembelajaran serta melakukan kegiatan tindak lanjut dalam bentuk pemberian tugas baik tugas individual maupun kelompok.

Dari hasil analisis dokumen, didapatkan bahwa kemampuan peserta diklat guru bahasa Arab dalam menyusun langkah-langkah pembelajaran mendapat nilai 75,70 dengan predikat mampu. Dari hasil analisis dokumen, guru sudah mencantumkan tiga kelompok kegiatan pendahuluan, inti dan penutup. Sebagian besar masih menggunakan langkah pembelajaran dengan lima urutan saintifik, mengamati, menanya, menganalisis, mencoba dan mengkomunikasikan secara urut. Sebagian guru dalam menyusun langkahlangkah pembelajaran sudah mengikuti sintak dari model pembelajaran yang digunakan. Dari telaah dokumen RPP, masih sedikit yang mengacu kepada tren pembelajaran keterampilan abad 21 yang di amanatkan oleh Kurikulum 2013 yang mengandung 4C (Communication, Collaborative, Critical thinking and Problem Solving serta Creativity and Innovation), Literacy, Penguatan Pendidikan Karakter dan High Order Thinking Skils (HOTS).

\section{h. Kemampuan merancang penilaian pembelajaran}

Penilaian merupakan tahap akhir dalam proses pembelajaran yang akan menentukan tingkat ketercapaian siswa dalam proses pembelajaran. Dalam tahapan ini, valid dan tidaknya penilaian sangat ditentukan cara guru dalam melaksanakan penilaian. Hal-hal pokok yang perlu diperhatikan dalam proses penilaian antara lain: 1) aspek penilaian meliputi sikap, pengetahuan, dan keterampilan; 2) teknik penilaian dan bentuk instrumen sesuai dengan indikator yang diajarkan; 3) dilengkapi dengan rumusan soal yang mudah dipahami dan rubrik penilaian.

Dari analisis data yang dilakukan oleh peneliti, kemampuan guru bahsa Arab dalam merancang penilaian pembelajaran mendapatkan nilai atau skor 64,30 dengan predikat cukup mampu. Guru bahasa Arab merancang penilaian dalam RPP nya, meskipun terkadang antara tagihan di penilaian tidak sesuai dengan indikator pencapaian kompetensi. Dalam merancang penilaian, guru sudah melakukan rancangan penilaian tiga aspek; sikap, pengetahuan dan keterampilan. Sebagian guru tidak mencantumkan penilaian dalam RPP nya. Sebagian hanya menyebutkan jenis-jenis penilaian tanpa menentukan penilaian yang tepat yang sesuai dengan indikatornya

\section{PENUTUP}

\section{Simpulan}

Meskipun Rencana Pelaksanaan Pembelajaran itu hanya sebuah administrasi guru dalam proses belajar mengajar, dan dalam prakteknya bisa berbeda dengan yang tertera dalam Rencana Pelaksanaan Pembelajara, tetapi kurangnya kemampuan guru dalam menyusun Rencana Pelaksanaan Pembelajaran akan menunjukkan tidak adanya rencana yang matang dalam pembelajaran. Dari hasil analisis data dokumen, menunjukkan bahwa dari delapan komponen atau aspek yang diteliti dalam penyusunan Rencana Pelaksanaan Pembelajaran, diketahui bahwa hanya komponen menyusun langkah-langkah pembelajaran, peserta mendapatkan predikat mampu. Ada tiga komponen peserta mendapatkan predikat cukup mampu, komponen lainnya memperoleh predikat kurang mampu. Dengan demikian dapat disimpulkan bahwa peserta diklat teknis substantif guru bahasa Arab tahun 2019, kurang mampu dalam menyusun Rencana Pelaksanaan Pembelajaran.. 


\section{Saran}

Mata pelajaran bahasa Arab merupakan mata pelajaran yang menjadi basis seluruh mata pelajaran agama di madrasah. Keberhasilan pembelajaran bahasa Arab menjadi modal utama siswa dalam mengikuti pembelajaran agama lainnya. Memperhatikan hasil penelitian, dapat kami rekomendasikan kepada pimpinan Balai Balai Diklat Keagamaan Semarang sebagai berikut: a. Melaksanakan Pendidikan dan Pelatihan khusus bagi guru Bahasa Arab disetiap tingkatan secara berkala.

b. Mencari narasumber yang berkompeten dalam pendidikan dan pelatihan guru bahasa Arab.

c. Memberikan kesempatan kepada MGMP Guru Bahasa Arab untuk Diklat di Wilayah Kerja bagi Guru Bahasa Arab.

\section{DAFTAR PUSTAKA}

Agus Setyawanto, Sunaryo HS, Imam Agus Basuki. (2012). Rencana Pelaksanaan Pembelajaran (RPP) Guru Bahasa Indonesia Tingkat SMP di Kota Malang. Jurnalonline.um.ac.id.

B. Mathew Miles dan Michael Huberman. (1992). Analisis Data Kualitatif Buku Sumber Tentang Metode-metode Baru. Jakarta: UIP.

Danim, S. (2002). Menjadi Peneliti Kualitatif. Bandung: Pustaka Setia.

De Porter, B., \& Mike, H. (1992). Quantum Learning. Membiasakan Belajar Nyaman dan Menyenangkan. (A. Abdurrahman, Penerj.) Bandung: Perbit Kaifa.

Djam'an, S. (2011). Metode Penelitian Kualitatif. Bandung: Alfabeta.

Hornby, A. (1995). Oxford Advanced Learner's Dictionary of Current English, First Edition. Oxford: Oxford University Press.

Horshit. (2014). Evaluation of Training and Development: An Analysis of Various Model. Journal of Bussiness and Management, 5(2), 16-17. doi:https://doi.org/10.9790/487X-0521622

Keputusan Menteri Agama Nomor 165 Tahun 2014 Tentang Pedoman Kurikulum Madrasah 2013

Latifah, F. A., Samsudi, \& Masrukan. (2014). Model Supervisi Akademik Kelompok Berbasis Think Talk Write Untuk Peningkatan Kemampuan Guru Menyusun Karya Tulis Ilmiah. Educational Management, 3(1). Diambil kembali dari https://journal.unnes.ac.id/sju/index.php/eduman/article/view/4357

Marwan, A. (2017). Membangun Gerakan Literasi. Dipetik September 7, 2019, dari http://harian.analisadaily.com/opini/news/membangungerakanliterasi/339316/2017/04/11

Mulyasa. (2005). Menjadi Guru Profesional. Bandung: PT. Remaja Rosda Karya.

Permendiknas Nomor 16 Tahun 2007 Tentang Standar Kualifikasi Akademik dan Kompetensi Guru 
Permendikbud Nomor 22 Tahun 2016 Tentang Standar Proses

Permendikbud Nomor 23 Tahun 2016 Tentang Standar Penilaian

Prastowo, A. (2013). Menyusun Rencana Pelaksanaan Pembelajaran Tematik Terpadu, Implementasi Kurikulum 2013. Jakarta: Kencana.

Pusdiklat Tenaga Teknis Pendidikan dan Keagamaan. (2018). Dokumen II Kurikulum Diklat Teknis Substantif Pendidikan. Jakarta: Pusdiklat Tenaga Teknis Pendidikan dan Keagamaan.

Sanjaya, W. (2010). Strategi Pembelajaran Berorientasi Standar Proses Pendidikan. Jakarta: Prenada Media Group.

Sardiman, A. (2001). Interaksi dan Motivasi Belajar Mengajar. Jakarta: Raja Grafindo Persada.

Steven, M. B., \& Anthony, F. S. (2000). The Leader Of The Future. New York: McMillan.

Sugiyono. (2007). Statistika untuk Penelitian. Bandung: CV Alfabeta.

Sukmadinata, N. (2011). Metode Penelitian Pendidikan. Bandung: Remaja Rosadakarya.

Suparno. (2000). Langkah-langkah Penulisan Artikel Ilmiah. Dalam A. Saukah, \& M. Waseno, Menulis Artikel untuk Jurnal Ilmiah. Malang: UM Press.

Suryawan, I. (2017). Peningkatan Pembelajaran K 13 (Penekanan 4C). Jakarta: Kemendikbud, Direktorat Jenderal Pendidikan Dasar dan Menengah, Direktorat Pembinaan Sekolah Menengah Atas.

Tea, T. (2009). Inspiring Teaching: Mendidik Penuh Inspirasi. Jakarta: Gema Insani. 